\title{
Transition state mimicry by glycosidase inhibitors: a critical kinetic analysis
}

\author{
Jacqueline Wicki, Spencer J. Williams ${ }^{\dagger}$, and Stephen G. Withers* \\ Department of Chemistry, W300-6174 University Blvd., University of British Columbia, \\ Vancouver, Canada V6T $1 Z 3$ \\ ${ }^{\dagger}$ Current Address: School of Chemistry, University of Melbourne, Parkville, Australia 3010.
}

\section{Supporting Information and Figures}

Supplementary Table S1: Kinetic parameters (at pH 7.0) for xylobiose-based inhibitors and o-nitrophenyl $\beta$-xylobioside with Cex and mutants of Cex.

\begin{tabular}{|c|c|c|c|c|c|c|c|c|}
\hline \multirow{2}{*}{ Cex Mutant } & \multirow{2}{*}{$\begin{array}{c}\text { ONPX }_{2} \\
k_{\text {cat }} \\
\left(\mathbf{s}^{-1}\right)\end{array}$} & \multirow{2}{*}{$\begin{array}{c}\mathrm{ONPX}_{2} \\
K_{\mathrm{m}} \\
(\mathrm{mM})\end{array}$} & \multirow{2}{*}{$\begin{array}{c}\text { ONPX }_{2} \\
k_{\text {cat }} / K_{\mathrm{m}} \\
\left(\mathrm{s}^{-1} \mathrm{mM}^{-1}\right)\end{array}$} & \multicolumn{5}{|c|}{ Compound $K_{\mathrm{i}}(\mu \mathrm{M})$} \\
\hline & & & & 1 & 2 & 3 & 4 & 5 \\
\hline Wild Type & 38 & 0.068 & 560 & 0.37 & 0.16 & 0.33 & 5.8 & 0.13 \\
\hline Asn169Ala & 29 & 0.05 & 580 & 2.1 & 0.41 & 1.5 & 17 & 0.12 \\
\hline GIn87Met & 55 & 0.13 & 420 & 4.9 & 1.1 & 2.1 & 18 & 0.39 \\
\hline GIn87Tyr & 46 & 0.22 & 210 & 16 & 6.4 & 11 & 62 & 1.2 \\
\hline Asn44Ala & 80 & 0.64 & 130 & 23 & 8.9 & 24 & 180 & 7.1 \\
\hline Glu43Ala & 47 & 1.6 & 30 & 110 & 22 & 96 & 2100 & 45 \\
\hline His80Asn & 0.14 & 0.016 & 8.6 & 350 & 87 & 340 & 370 & 13 \\
\hline His80Ala & 0.33 & 0.039 & 8.4 & 140 & 43 & 1000 & 800 & 5.9 \\
\hline Asn126Ala & 2.9 & 0.39 & 7.3 & 1300 & 200 & 2000 & 4800 & 1.6 \\
\hline His80GIn & 0.039 & 0.01 & 3.8 & 1300 & 350 & 340 & 590 & 6.7 \\
\hline Lys47Ala & 9.7 & 8.5 & 1.2 & 2300 & 1000 & 2300 & 6600 & 870 \\
\hline
\end{tabular}



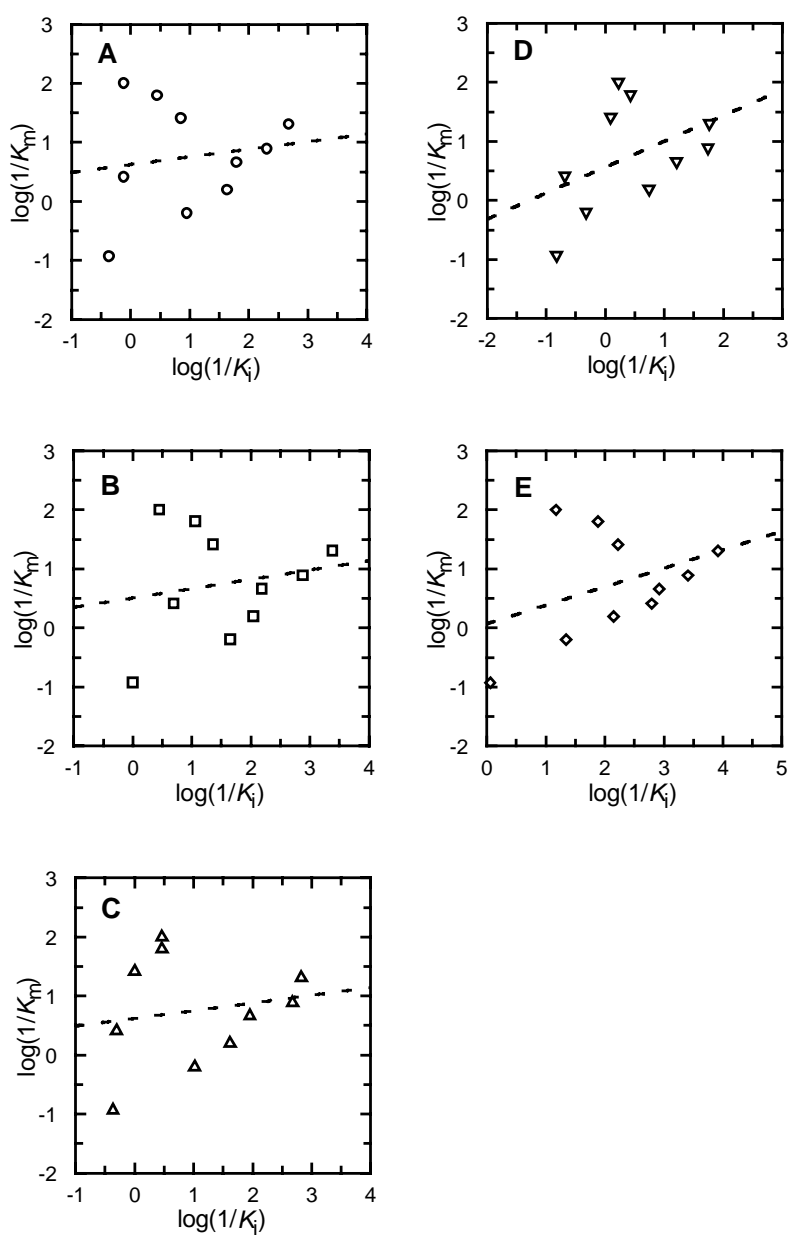

Supplementary Figure S1. Comparison between o-nitrophenyl $\beta$-xylobioside $\mathrm{K}_{\mathrm{m}}$ values and inhibitor $\mathrm{K}_{\mathrm{i}}$ for $x y l o b i o s e-$ based (A) lactam oxime, (B) imidazole, (C) isofagomine lactam, (D) deoxynojirimycin, and (E) isofagomine. 


\section{Experimental Details}

General Methods. The glycoside substrate, $o$-nitrophenyl $\beta$-xylobioside, was synthesized as described previously. ${ }^{1}$ As well, the syntheses of all five xylobiosylderived inhibitors have been described previously. 2,3 All buffer reagents, unless otherwise specified, were of analytical or HPLC grade and were obtained from Sigma or BDH. Growth media components were from Sigma. Plasmid-containing strains were grown in Luria Broth containing $100 \mu \mathrm{g} / \mathrm{mL}$ ampicillin or $50 \mu \mathrm{g} / \mathrm{mL}$ kanamycin. $P$ wo DNA polymerase and deoxynucleoside triphosphates were obtained from Roche. $P f u$ DNA polymerase was from Promega. Restriction endonucleases and T4 DNA ligase were from New England BioLabs unless otherwise indicated. Escherichia coli One Shot $^{\mathrm{TM}}$ TOP10 competent cells were from Invitrogen. The QuikChange ${ }^{\mathrm{TM}}$ Site-Directed Mutagenesis Kit and Epicurian Coli ${ }^{\circledR}$ XL1-Blue electroporation-competent cells were from Stratagene. BugBuster protein extraction reagent was from Novagen. PCR DNA fragment purification and plasmid purification kits were from Qiagen or Promega. Plasmid pUC12-1.1cex(PTIS) has been described. ${ }^{4}$ Cex and the CexQ87 mutants were constructed and purified as described previously. 5

Construction of mutants. The genes encoding for cex H80A, H80N, H80Q, K47A, N44A, E43A, N126A and N169A were linearly amplified following the protocol outlined in Stratagene's QuikChange ${ }^{\text {тм }}$ Site-Directed Mutagenesis Kit. Synthesis of oligonucleotide primers (Table S2) and DNA sequencing was performed by the Nucleic Acids and Peptide Services Unit at the University of British Columbia (Vancouver, Canada). 
Supplementary Table S2: Primers used in the mutagenesis of C. fimi xylanase.

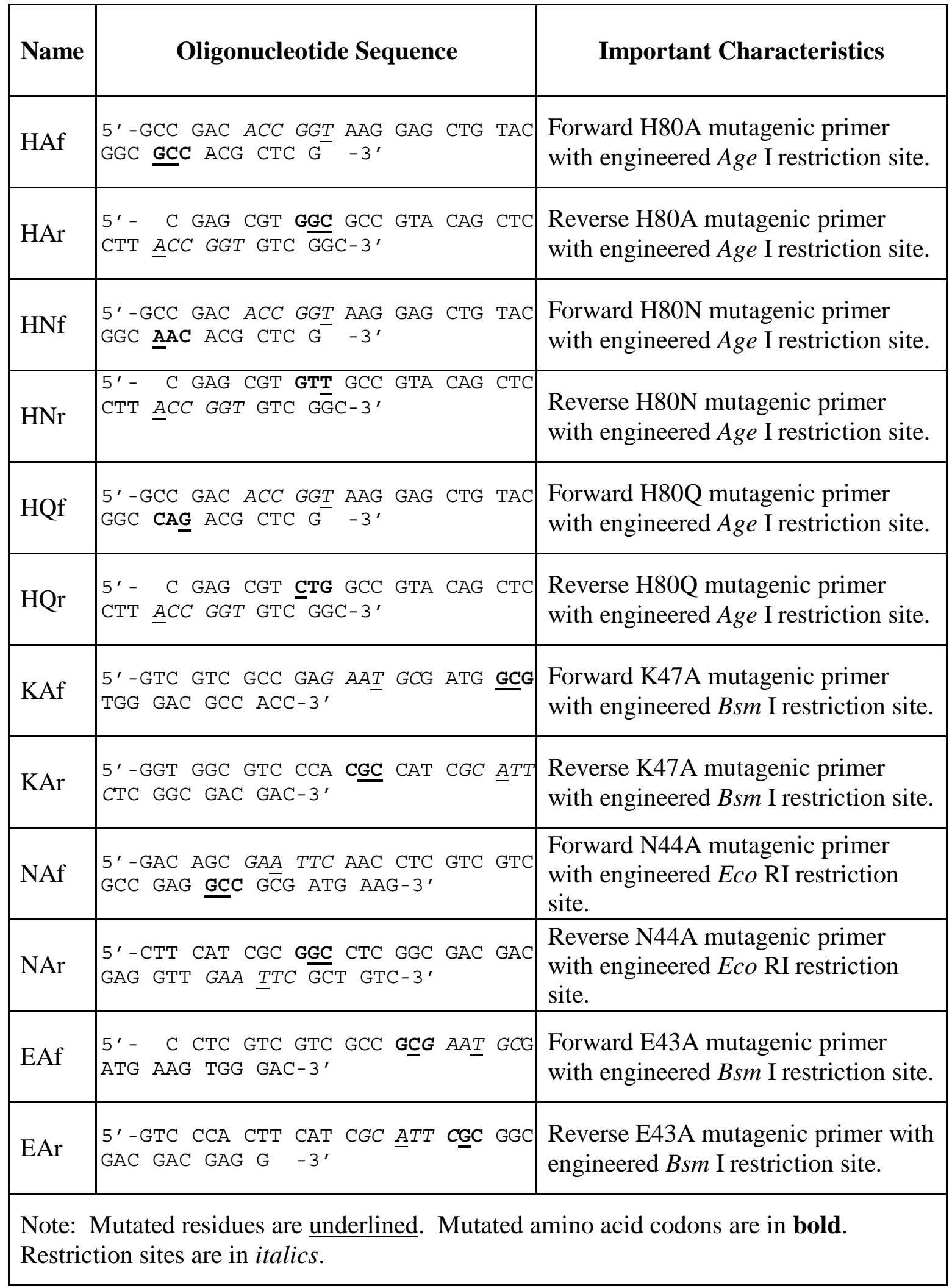


The reaction mixture contained $150 \mathrm{ng}$ oligonucleotide primers, $250 \mu \mathrm{M}$ each of the four deoxynucleoside triphosphates, and $50 \mathrm{ng}$ of plasmid pUC12-1.1cex(PTIS) in $50 \mu \mathrm{L}$ of $P f u$ DNA polymerase reaction buffer containing 8\% DMSO. The reaction was initiated by adding $4 \mathrm{U}$ of $P f u$ DNA polymerase (Promega). After heating the reaction mixture to $95^{\circ} \mathrm{C}$ for $30 \mathrm{~s}$, sixteen cycles $\left(30 \mathrm{~s}\right.$ at $95^{\circ} \mathrm{C}, 1 \mathrm{~min}$ at $55^{\circ} \mathrm{C}$, and $9 \mathrm{~min}$ at $68^{\circ} \mathrm{C}$ ) were performed in a thermal cycler (GeneAmp ${ }^{\circledR}$ PCR System 2400, Perkin Elmer). Agarose gel electrophoresis confirmed the presence of sufficient amplification product. The parental supercoiled dsDNA was digested with 20 U Dpn I restriction enzyme at $37^{\circ} \mathrm{C}$ for 1 hour. Epicurian $\mathrm{Coli}^{\circledR} \mathrm{XL1-Blue} \mathrm{electroporation-competent} \mathrm{cells} \mathrm{(Stratagene)}$ were subsequently transformed with $1 \mu \mathrm{L}$ of the $D p n$ I treated DNA from the amplification reaction using a BioRad GenePulser ${ }^{\circledR} \mathrm{II}$ and $0.1 \mathrm{~cm}$ cuvettes under the following conditions: $1.8 \mathrm{kV}, 25 \mu \mathrm{F}, 200 \Omega$. The cells were plated on LB agar plates containing $100 \mu \mathrm{g} / \mathrm{mL}$ ampicillin and incubated at $37^{\circ} \mathrm{C}$ overnight. Single colonies were selected and grown overnight in LB media containing $100 \mu \mathrm{g} / \mathrm{mL}$ ampicillin. Plasmid DNA was isolated and stored in water at $-20^{\circ} \mathrm{C}$. Restriction endonuclease mapping revealed positive clones, which were subsequently sequenced to verify the correct mutations. The confirmed cloned product plasmids were subsequently transformed into electrocompetent E. coli JM101 cells using the BioRad GenePulser ${ }^{\circledR}$ II and $0.2 \mathrm{~cm}$ cuvettes under the following conditions: $2.5 \mathrm{kV}, 25 \mu \mathrm{F}, 400 \Omega$. Cells were selected by the ampicillin resistance conferred by pUC12-1.1 on LB $_{\text {amp }}$ agar plates. Single colonies were selected and grown overnight in $\mathrm{LB}_{\mathrm{amp}}$ for long-term storage in $10 \%$ DMSO at $-70^{\circ} \mathrm{C}$.

Production of mutant proteins. E. coli JM101 transformants from the previously prepared DMSO stocks were selected on $\operatorname{LB}_{\mathrm{amp}}(100 \mu \mathrm{g} / \mathrm{mL})$ agar plates. A single colony was picked and grown for 6 hours in $3 \mathrm{~mL}$ of $\mathrm{LB}_{\mathrm{amp}}$, and this culture was subsequently used to inoculate $1 \mathrm{~L}$ of $\mathrm{TYP}_{\mathrm{amp}}$ [yeast extract $\left(16 \mathrm{~g} \mathrm{~L}^{-1}\right)$, tryptone $\left(16 \mathrm{~g} \mathrm{~L}^{-1}\right), \mathrm{NaCl}\left(5 \mathrm{~g} \mathrm{~L}^{-1}\right), \mathrm{K}_{2} \mathrm{HPO}_{4}\left(2.5 \mathrm{~g} \mathrm{~L}^{-1}\right)$, and ampicillin $\left.\left(100 \mu \mathrm{g} \mathrm{mL}^{-1}\right)\right]$. After the culture grew to an $\mathrm{OD}_{600}$ of $2-3$ at $30-37^{\circ} \mathrm{C}, 0.2 \mathrm{mM}$ isopropyl $\beta$-D-thiogalactoside (IPTG) was added to induce protein expression and grown for an additional 4 hours at $25^{\circ} \mathrm{C}$. Induced cells were harvested by centrifugation at $5000 \mathrm{rpm}$ for 20 minutes at $4^{\circ} \mathrm{C}$. 
A cell extract was prepared using BugBuster ${ }^{\mathrm{TM}}$ Protein Extraction Reagent. The soluble cell extract was added to $450 \mathrm{~mL}$ of $500 \mathrm{mM} \mathrm{NaCl}$ in $50 \mathrm{mM}$ sodium phosphate buffer (pH 7.0). EDTA and PMSF were added to $0.5 \mathrm{mM}$.

Cex was purified from the clarified cell extract by affinity chromatography on cellulose. $^{6}$ Approximately $25 \mathrm{~g}$ of CF1 cellulose (Sigma) was gently stirred with distilled water, allowed to settle, and the "cellofines" were decanted. The remaining cellulose was packed into an XK50/20 column (Pharmacia), yielding a column volume of approximately $150 \mathrm{~mL}$. The column was attached to an FPLC system (Pharmacia) and equilibrated with 5 column volumes of $500 \mathrm{mM} \mathrm{NaCl}$ in $50 \mathrm{mM}$ sodium phosphate buffer $(\mathrm{pH} 7.0)$ at a flow rate of $5 \mathrm{~mL} / \mathrm{min}$. The soluble cell extract from the $1 \mathrm{~L}$ cell culture was applied to the column at a flow rate of $5 \mathrm{~mL} / \mathrm{min}$. The column was washed with 2 column volumes of $500 \mathrm{mM} \mathrm{NaCl}$ in $50 \mathrm{mM}$ sodium phosphate buffer ( $\mathrm{pH} \mathrm{7.0)}$ followed by 1 column volume of $50 \mathrm{mM}$ sodium phosphate buffer $(\mathrm{pH} 7.0)$ at a flow rate of $5 \mathrm{~mL} / \mathrm{min}$. Cex protein was eluted with 2.5 column volumes of distilled $\mathrm{H}_{2} \mathrm{O}$ at a flow rate of $5 \mathrm{~mL} / \mathrm{min}$. The absorbance of the eluate was measured continuously at $280 \mathrm{~nm}$, and appropriate fractions were pooled and passed through a $0.22 \mu \mathrm{m}$ filter (Millipore).

The protein sample was further purified on a $5 \mathrm{~mL}$ HiTrap Mono Q HP column attached to an FPLC system (Pharmacia). The column was washed with 5 column volumes of $20 \mathrm{mM}$ Tris- $\mathrm{HCl}$ buffer ( $\mathrm{pH} 7.5$ ), 5 column volumes of $20 \mathrm{mM}$ Tris- $\mathrm{HCl}$ buffer containing $1 \mathrm{M} \mathrm{NaCl}$ ( $\mathrm{pH} 7.5$ ), and then 10 column volumes of $20 \mathrm{mM}$ Tris- $\mathrm{HCl}$ buffer ( $\mathrm{pH} 7.5)$ at a flow rate of $5 \mathrm{~mL} / \mathrm{min}$. The protein sample was adjusted to $\mathrm{pH} 8.0$ with $20 \mathrm{mM}$ Tris- $\mathrm{HCl}$ and applied onto the HiTrap Mono Q HP column at a flow rate of $5 \mathrm{~mL} / \mathrm{min}$. The column was washed with 4 column volumes of $20 \mathrm{mM}$ Tris-HCl buffer $(\mathrm{pH} 7.5)$. Cex protein was eluted from the anion-exchange column with a linear $\mathrm{NaCl}$ gradient from 0 to $500 \mathrm{mM}$ in a buffer containing $20 \mathrm{mM}$ Tris- $\mathrm{HCl}(\mathrm{pH} \mathrm{7.5)}$. Fractions $(8 \mathrm{~mL})$ were collected at a flow rate of $5.0 \mathrm{~mL} / \mathrm{min}$ and analyzed using SDSpolyacrylamide gel electrophoresis on a Mini-PROTEAN II apparatus (BioRad). Protein bands were visualized by staining with Coomassie Blue. Fractions containing pure enzyme were pooled and stored at $4^{\circ} \mathrm{C}$. If necessary, the enzyme was concentrated to at least $2.0 \mathrm{mg} / \mathrm{mL}$ using a Centriprep concentrator (30 kDa cutoff) from Amicon. Final protein concentration was calculated from measured absorbance $280 \mathrm{~nm}$ using the 
previously determined extinction coefficient for Cex $\left(\varepsilon_{280}=1.61 \mathrm{~mL} \mathrm{mg}^{-1} \mathrm{~cm}^{-1}\right)(\mathrm{D}$. Tull, MSc Thesis, University of British Columbia).

Characterization of mutants. The molecular weights of purified Cex and Cex mutants were determined by Ion Spray Mass Spectrometry performed on a PE SCIEX API 300 ion spray LC/MS system.

Kinetic studies. Kinetic studies (Table S1) were performed in $50 \mathrm{mM}$ $\mathrm{NaH}_{2} \mathrm{PO}_{4} / \mathrm{Na}_{2} \mathrm{HPO}_{4}$ buffer ( $\mathrm{pH} 7.0$ ), containing $0.1 \% \mathrm{w} / \mathrm{v}$ bovine serum albumin (BSA) at $37^{\circ} \mathrm{C}$, as described. 7,8 Initial enzymic hydrolysis rates were determined by continuous measurement of the release of the substituted phenol product using a Unicam UV4 spectrophotometer equipped with a temperature-controlled circulating water bath. Solutions of the appropriate substrate concentrations were incubated within the spectrophotometer until thermally equilibrated; reactions were initiated by the addition of enzyme. In order to ensure linear kinetics and to obtain a sufficient absorbance change for accurate calculation of the rates, the concentration of enzyme added and the length of time that the reaction was monitored was selected such that less than $10 \%$ of the total substrate was converted to product. Enzyme-catalyzed hydrolysis for each mutant was measured at 8 to 10 different substrate concentrations ranging from about $0.1 K_{\mathrm{m}}$ to $7 K_{\mathrm{m}}$, where practical. Values for $K_{\mathrm{m}}$ and $k_{\text {cat }}$ were determined from the initial rates of hydrolysis $\left(V_{0}\right)$ versus substrate concentration by non-linear regression analysis using the computer program GraFit 4.0.9

Inhibition constants (Table S1) were determined at $37^{\circ} \mathrm{C}$ using a $50 \mathrm{mM}$ $\mathrm{NaH}_{2} \mathrm{PO}_{4} / \mathrm{Na}_{2} \mathrm{HPO}_{4}$ buffer (pH 7.0) containing $0.1 \%$ w/v BSA and 2,4-dinitrophenyl $\beta$-cellobioside as a substrate. Measurements were started by addition of enzyme. Measurements of the increase of absorption at $400 \mathrm{~nm} / \mathrm{min}$ in a continuous assay yielded reaction rates. Estimates of $K_{\mathrm{i}}$ values were obtained by measuring rates at a fixed substrate concentration with a range of inhibitor concentrations (6-10) which encompassed the $K_{\mathrm{i}}$ value ultimately determined, generally from $0.33 K_{\mathrm{i}}$ to $3 K_{\mathrm{i}}$. The observed rates were plotted in the form of a Dixon plot and the $K_{\mathrm{i}}$ value was determined 
(assuming competitive inhibition) by an intersection of this line with a horizontal line drawn through $1 / V_{\max }$.

\section{References}

1) Ziser, L.; Withers, S. G. Carbohydr. Res. 1994, 265, 9-17.

2) Williams, S. J.; Notenboom, V.; Wicki, J.; Rose, D. R.; Withers, S. G. J. Am. Chem. Soc. 2000, 122, 4229-4230.

3) Williams, S. J.; Hoos, R.; Withers, S. G. J. Am. Chem. Soc. 2000, 122, 2223-2235.

4) O'Neill, G. P.; Goh, S. H.; Warren, R. A. J.; Kilburn, D. G.; R. C. Miller, J. Gene 1986, 44, 325-330.

5) Notenboom, V.; Birsan, C.; Warren, R. A. J.; Withers, S. G.; Rose, D. R. Biochemistry 1998, 37, 4751-4758.

6) MacLeod, A. M.; Lindhorst, T.; Withers, S. G.; Warren, R. A. J. Biochemistry 1994, 33, 6371-6376.

7) Tull, D.; Withers, S. G. Biochemistry 1994, 33, 6363-6370.

8) MacLeod, A. M.; Tull, D.; Rupitz, K.; Warren, R. A. J.; Withers, S. G. Biochemistry 1996, 35, 13165-13172.

9) Leatherbarrow, R. J. GraFit 4.0; 4.0.21 ed.; Erithacus Software Limited, 1989. 